\title{
Can Routine Clinical Tests for Protein Intake and Physical Function Predict Successful Weight Loss?
}

Citation for published version (APA):

Holthuijsen, D. D. B., Romeijn, M. M., Kolen, A. M., Janssen, L., Schep, G., van Dielen, F. M. H., \& Leclercq, W. K. G. (2022). Can Routine Clinical Tests for Protein Intake and Physical Function Predict Successful Weight Loss? Bariatric Surgical Practice and Patient Care, 17(2), 85-91. https://doi.org/10.1089/bari.2021.0048

Document status and date:

Published: 01/06/2022

DOI:

10.1089/bari.2021.0048

Document Version:

Publisher's PDF, also known as Version of record

Document license:

Taverne

Please check the document version of this publication:

- A submitted manuscript is the version of the article upon submission and before peer-review. There can be important differences between the submitted version and the official published version of record.

People interested in the research are advised to contact the author for the final version of the publication, or visit the DOI to the publisher's website.

- The final author version and the galley proof are versions of the publication after peer review.

- The final published version features the final layout of the paper including the volume, issue and page numbers.

Link to publication

\footnotetext{
General rights rights.

- You may freely distribute the URL identifying the publication in the public portal. please follow below link for the End User Agreement:

www.umlib.nl/taverne-license

Take down policy

If you believe that this document breaches copyright please contact us at:

repository@maastrichtuniversity.nl

providing details and we will investigate your claim.
}

Copyright and moral rights for the publications made accessible in the public portal are retained by the authors and/or other copyright owners and it is a condition of accessing publications that users recognise and abide by the legal requirements associated with these

- Users may download and print one copy of any publication from the public portal for the purpose of private study or research.

- You may not further distribute the material or use it for any profit-making activity or commercial gain

If the publication is distributed under the terms of Article $25 \mathrm{fa}$ of the Dutch Copyright Act, indicated by the "Taverne" license above, 


\title{
Can Routine Clinical Tests for Protein Intake and Physical Function Predict Successful Weight Loss?
}

\author{
Daniëlle D.B. Holthuijsen, MSc, ${ }^{1,2, *}$ Marleen M. Romeijn, MD, ${ }^{1,3, *, i}$ \\ Aniek M. Kolen, MSc, ${ }^{1,2}$ Loes Janssen, PhD, ${ }^{1}$ Goof Schep, MD, PhD, ${ }^{4}$ \\ François M.H. van Dielen, MD, PhD, and Wouter K.G. Leclercq, MD ${ }^{1}$
}

\begin{abstract}
Background: Protein intake and physical activity have a substantial impact on body composition and weight loss outcomes after bariatric surgery. The 24-h dietary recall and 6-min walk test (6mWT) are frequently used to monitor protein intake and physical activity, respectively. Despite its frequent use, it is unknown whether these tests can predict long-term weight loss.

Methods: This retrospective study included 85 patients who underwent laparoscopic Roux-en-Y gastric bypass. Protein intake was recorded using the 24-h dietary recall and physical function was measured using the $6 \mathrm{mWT}$. Data about total weight loss (TWL) and nonresponse (i.e., insufficient weight loss and weight regain) were collected up to 5 years. Multiple regression analyses were performed to examine the predictive value of the 24-h dietary recall and $6 \mathrm{mWT}$ on weight loss outcomes.

Results: The mean protein intake 1 year postoperatively was $68.1 \pm 15.0 \mathrm{~g} /$ day and the mean distance covered during the $6 \mathrm{mWT}$ was $591.7 \pm 67.9 \mathrm{~m}$. Both the 24 -h dietary recall and $6 \mathrm{mWT}$ were not significantly associated with TWL and neither with nonresponse.

Conclusions: The 24-h dietary recall and $6 \mathrm{mWT}$ are poor predictors for long-term weight loss outcomes after gastric bypass. Despite the well-known advantages of these clinical tests, other monitoring tests are suggested for future research.
\end{abstract}

Keywords: bariatric surgery, gastric bypass, 24-h dietary recall, 6-minute walk test, weight loss

\section{Introduction}

B ARIATRIC SURGERY IS considered the most effective treatment in patients with morbid obesity as it promotes significant long-term weight loss and reduces obesity-related comorbidities. $^{1-3}$ Despite its frequent success, $20-30 \%$ of patients do not respond well to bariatric surgery. ${ }^{4,5}$ These patients may experience insufficient weight loss, defined as primary nonresponse, or regain an excessive amount of weight after sufficient weight loss, defined as secondary nonresponse. ${ }^{6}$ In the etiology of nonresponse, studies provided evidence for surgical components like a dilated gastric pouch and/or anastomosis, as well as for physiological components like gender, preoperative body mass index (BMI), and preoperative age. ${ }^{7,8}$ In addition to these components it is thought that nutritional noncompliance and physical inactivity may contribute to the development of nonresponse. ${ }^{9,10}$ The mechanisms behind this are discussed below.

The recommended protein intake in patients following bariatric surgery is $60-120 \mathrm{~g} /$ day or $1.1-1.5 \mathrm{~g} / \mathrm{kg}$ of ideal body weight. ${ }^{1-13}$ An inadequate amount of protein intake could reduce the feelings of satiety and result in a loss of fat-free mass rather than fat mass. ${ }^{14-16}$ This may, in turn, induce a decrease in the resting metabolic rate and negatively alter weight loss outcomes. ${ }^{14-16}$ In terms of physical activity and bariatric surgery, guidelines recommend patients to perform both resistance and endurance training on moderate-tovigorous intensity for $150-250 \mathrm{~min} /$ week to prevent weight regain and $300 \mathrm{~min} /$ week to maintain weight loss. ${ }^{12,14,17}$ Low activity levels can only moderately contribute to the positive effects of physical activity, which are an increased total energy expenditure, preservation of fat-free mass and enhancement and/or maintenance of postsurgical weight loss..$^{9,12,18}$

\footnotetext{
${ }^{1}$ Department of Surgery, Máxima Medical Center, Veldhoven, The Netherlands.

${ }^{2}$ Faculty of Health, Medicine and Life Sciences, Maastricht University, Maastricht, The Netherlands.

${ }^{3}$ Department of Surgery, Research School NUTRIM, Maastricht University Medical Center+, Maastricht, the Netherlands.

${ }^{4}$ Department of Sport Medicine, Máxima Medical Center, Veldhoven, The Netherlands.

*These authors would like to share first authorship as they contributed equally to the work.

iORCID ID (https://orcid.org/0000-0001-6582-5255).
} 
In light of weight loss outcomes, it is of high clinical importance to thoroughly monitor protein intake and physical function. The 24-h dietary recall method is a well-known instrument for nutritional assessment, ${ }^{19}$ whereas the 6-min walk test $(6 \mathrm{mWT})$ is a commonly described instrument for assessment of a patients' functional capacity. ${ }^{20,21}$ Both the 24-h dietary recall method and 6mWT are fast, inexpensive, and easy executable tests. ${ }^{19,20,22}$ Because of these clinical advantages, it is presumed that the tests are frequently used in today's practice. Despite this, it is unknown how well these clinical tests can actually predict long-term weight loss after bariatric surgery. Therefore, this study aimed to determine the predictive value of the 24-h dietary recall and $6 \mathrm{mWT}$ on long-term weight loss outcomes.

\section{Materials and Methods}

\section{Study population}

Data of patients who underwent primary laparoscopic Roux-en-Y gastric bypass (RYGB) in a European bariatric center of excellence in 2014 were retrospectively analyzed. Patients were included if their body weight was noted 18 months after surgery and 2, 3, 4, or 5 years after surgery; and if their protein intake $(24 \mathrm{~h}$ recall) and physical function (6-min walk test) were reported 1 year postoperatively. Patients who underwent a primary banded RYGB or oneanastomosis gastric bypass were excluded for the sake of uniformity. Patients with a previous history of bariatric surgery such as laparoscopic adjustable gastric banding or Mason gastroplasty were excluded as well. At last, patients were excluded if they underwent revisional bariatric surgery due to nonresponse, as this interfered with weight loss outcomes. Ethics approval has been obtained from the Medical Ethics Committee of our center, reference number N20.045, date of approval 10-04-2020. For this type of study, formal consent from all individual participants was not required. The study was conducted according to the guidelines of the Declaration of Helsinki, and was approved by the Ethics Committee of the Máxima Medical Center (protocol code N20.045, date of approval 10-4-2020). Clinical Trial Registration is not applicable.

\section{Standard pre- and postoperative care}

All patients were screened for primary bariatric surgery in our center by a multidisciplinary team in accordance with the International Federation for the Surgery of Obesity and Metabolic Disorder guidelines. ${ }^{23}$ An individual preoperative treatment with the dietician, physiotherapist, and/or medical psychologist was offered in addition to the regular program if the multidisciplinary team decided that this was necessary. The postoperative program included individual and group visits with a dietician and physical therapist with the aim to adopt a healthy lifestyle. Patients were advised to consume three meals and three healthy snacks per day, drink 1.5-2 L throughout the day, and add $30 \mathrm{~g}$ protein (whey) powder to their meals or drinks during the first 3 weeks after surgery. Furthermore, patients were advised to adhere to the Dutch Physical Activity Guidelines ${ }^{24}$ and were, 4 weeks postoperatively, invited to participate in a training program at our center. Patients were offered two training sessions per week for 5-6 weeks, each session consisting of 30-min endurance training and 30-min resistance training. The intensity of the resistance training is calculated from one repetition maximum (1RM), starting from $50 \%$ to $60 \%$ of 1RM up to $70-$ $80 \%$ of $1 \mathrm{RM}$, while the intensity of the endurance training is calculated from steep ramp test (SRT) and 6mWT, aiming levels of Borg scale 13-15. Patients were annually monitored for a period of 5 years with standard biochemical testing for vitamin deficiencies.

\section{Twenty-four-hour dietary recall}

The 24-h dietary recall method was routinely used 1 year postoperatively to estimate protein intake. During a 30-min assessment with a clinical dietician, patients were orally questioned about their diet from the past $24 \mathrm{~h}$ (from midnight to midnight) of, preferably, a weekday. Based on current guidelines, patients were categorized as "adequate protein intake" if their protein intake was $\geq 60 \mathrm{~g} /$ day, whereas patients were categorized as "inadequate protein intake" if their protein intake was $<60 \mathrm{~g} /$ day. ${ }^{13,14}$

\section{Six-minute walk test}

The $6 \mathrm{mWT}$ was routinely performed preoperatively and 1 year postoperatively to determine physical function. The test was executed according to a standardized protocol. ${ }^{25}$ Patients were instructed to walk at their own pace as far as possible for $6 \mathrm{~min}$ by going back and forth in an at least $25-\mathrm{m}$ long corridor. Outcomes were total distance covered in meters $(\mathrm{m})$ and heart rate at rest and immediately after the test ended. The percentage of the predicted value of the distance covered was calculated as follows ${ }^{26}:[(218+5.14 *$ height (cm) $-5.32 *$ age (years) $-1.8 *$ weight $(\mathrm{kg})+51.31 * \operatorname{sex}(1-$ male, 0 -female)]. Numbers of $<82 \%$ were considered aberrant based on normative values of an obese population. ${ }^{27}$ After the 6mWT, leg cramps and shortness of breath (dyspnea) were rated by the Borg scale. This is a 15-point scale ranging from 6 ("nothing at all") to 20 ("very, very severe"). Patients were categorized as "high physical function" if the predicted percentage was $\geq 82 \%$, whereas patients were categorized as "low physical function" if their predicted percentage was $<82 \%$.

\section{Body weight and obesity-related comorbidities}

Body weight was measured during preoperative screening and hospital consultation 12 and 18 months, and 2, 3, 4, and 5 years postoperative. The presence of obesity-related comorbidities (hypertension, diabetes, dyslipidemia, obstructive sleep apnea syndrome (OSAS), and osteoarthritis) was assessed as well. Weight loss was described as \% total weight loss (\%TWL), and was calculated as [(preoperative weight postoperative weight)/preoperative weight] $\times 100 \%$. The $\%$ TWL at 2 and 3 years after RYGB were averaged into $\%$ TWL at midterm, and \%TWL at 4 and 5 years after RYGB were averaged into \% TWL at long term. The percentage of weight regain was calculated as percentage kilogram $(\mathrm{kg})$ gained after reaching the lowest postoperative weight (nadir weight). Nonresponse rates were defined as the following: primary nonresponse if the patients' \% TWL was less than $15 \%$ within the first 18 months after surgery, and secondary nonresponse if the patients' \% TWL was more than $15 \%$ plus a regain of more than $15 \%$ after 24 months, with respect to nadir weight following $\mathrm{RYGB} .^{28}$ 
Table 1. Baseline Characteristics of The Study Population

\begin{tabular}{lc}
\hline & $\mathrm{n}=85$ \\
\hline Gender, no. (\%) & \\
Female & $69(81.2)$ \\
Male $^{\mathrm{Age}}(\mathrm{years})^{\mathrm{b}}$ & $16(18.8)$ \\
${\text { Preoperative weight }(\mathrm{kg})^{\mathrm{c}}}^{\mathrm{c}}$ & $45.8 \pm 10.2(23-66)$ \\
${\text { Preoperative BMI }\left(\mathrm{kg} / \mathrm{m}^{2}\right)^{\mathrm{c}}}$ & $124.0(104.3)$ \\
Preoperative comorbidities, no. (\%) & $42.0(34.6)$ \\
Hypertension & \\
Type II diabetes & $37(43.5)$ \\
Dyslipidemia & $11(12.9)$ \\
OSAS & $18(21.2)$ \\
Osteoarthritis & $17(20.0)$ \\
No comorbidities & $8(9.4)$ \\
Preoperative individual treatment, no. (\%) & $33(39.0)$ \\
Intern & \\
Dietician & $25(29.4)$ \\
Physiotherapist & $7(8.2)$ \\
Medical psychologist & $0(0.0)$ \\
Extern & $20(23.5)$ \\
Complications, no. (\%) & $1(1.2)$ \\
Short term <30 days & \\
Long term $>30$ days & $1(1.2)$ \\
\hline
\end{tabular}

${ }^{\mathrm{a}} \mathrm{Age}$ at time of surgery.

${ }^{\mathrm{b}}$ Expressed in mean $\pm \mathrm{SD}$ (range).

${ }^{c}$ Expressed in median (IQR 25-75).

OSAS, obstructive sleep apnea syndrome; BMI, body mass index; $\mathrm{SD}$, standard deviation; IQR, interquartile range.

\section{Statistical analyses}

Descriptive statistics were computed for patient characteristics. Quantitative data are presented as mean with standard deviation (range) or median with interquartile range, and categorical data are expressed in numbers and percentages. Data were checked for normality using the Kolmogorov-Smirnov test. A paired t-test, or Wilcoxon signed-rank test in case of a non-normal distribution, was performed to compare pre- and postmeasurements of physical function. A two-stage hierarchical multiple linear regression analysis was conducted to examine the contribution of protein intake (postoperatively assessed) and physical function (both preoperatively and postoperatively assessed) on \% TWL at midterm and \% TWL at long term. Both analyses were performed with protein intake and physical function as categorical and continuous variable. Furthermore, a two-stage hierarchical multiple logistic regression analysis was performed to examine the relation between protein intake and physical function on secondary nonresponse. To test whether associations were independent of other predictors, potential confounders were included as covariates (i.e., age, gender, preoperative BMI, preoperative individual treatment, and long-term complications). Statistical significance was set at $p \leq 0.05$. All analyses were performed using the program Statistical Package for Social Sciences version number 22.0 (IBM SPSS 22.0; Chicago, IL).

\section{Results}

\section{Study population}

A total of 227 patients were assessed. Four patients were excluded due to revisional surgery (2 patients underwent shortening of the common limb; 1 patient received a gastric ring; 1 patient underwent resizing of the stoma). Furthermore, 138 patients were excluded due to missing values in essential variables at various time points. In total 85 patients, of which $69(81.2 \%)$ were female, were included in the study. Mean age was $45.8 \pm 10.2$ years and median BMI preoperatively was $42.0 \mathrm{~kg} / \mathrm{m}^{2}$ (interquartile range $=34.6$ ). These and other patients' demographics are presented in Table 1.

\section{Protein intake and physical function}

Mean protein intake 1 year after surgery was $68.1 \pm 15.0 \mathrm{~g} /$ day and the mean distance covered during the $6 \mathrm{mWT}$ was $591.7 \pm 67.9 \mathrm{~m}$. In total, $61.2 \%$ of the patients were grouped into "adequate protein intake" and $38.8 \%$ of the patients were grouped into "inadequate protein intake". Moreover, $37.6 \%$ of the patients were grouped into "low physical function", whereas $62.4 \%$ was grouped into "high physical function" (Table 2).

\section{Weight outcomes}

The follow-up rate was $96 \%$ at midterm and $85 \%$ at long term. The percentage of TWL was $34.7 \% \pm 8.6 \%$ at 1.5 years,

Table 2. Physical Function at Baseline and 1 Year Follow-Up

\begin{tabular}{|c|c|c|c|c|c|c|}
\hline & & $\mathrm{N}$ & Baseline & $\mathrm{n}$ & 1 year follow-up & $\mathrm{p}$-value \\
\hline SRT & Steep ramp test (Watt) ${ }^{\mathrm{a}}$ & 85 & $160.0(220.0)$ & & N/A & \\
\hline $6 \mathrm{mWT}$ & $\begin{array}{l}\text { Distance covered }(\mathrm{m})^{\mathrm{b}} \\
\text { Predicted percentage }(\%)^{\mathrm{b}} \\
\text { Heart rate at rest (beats/min) } \\
\text { Heart rate after effort (beats/min) } \\
\text { Borg score for dyspnea } \\
\text { Borg score for leg fatigue } \\
\text { Borg sical function } \\
\text { Physical } \\
\text { High physical function, no (\%) } \\
\text { Low physical function, no. }(\%)\end{array}$ & $\begin{array}{l}85 \\
85 \\
84 \\
85 \\
85 \\
85 \\
85\end{array}$ & $\begin{aligned} & 520.7 \pm 78.0(300.0-688.0) \\
& 81.7 \pm 9.9(48.0-107.0) \\
& 87.3 \pm 14.5(55.0-139.0) \\
& 126.5 \pm 18.8(85.0-195.0) \\
& 12.0(13.0) \\
& 13.0(12.0) \\
& 46(54.1) \\
& 39(45.9)\end{aligned}$ & $\begin{array}{l}85 \\
85 \\
73 \\
71 \\
77 \\
77 \\
85\end{array}$ & $\begin{aligned} & 591.7 \pm 67.9(432.0-778.0) \\
& 83.4 \pm 8.0(65.0-103.0) \\
& 75.3 \pm 12.5(51.0-102.0) \\
& 107.5 \pm 19.3(65.0-162.0) \\
& 11.0(3.0) \\
& 11.0(11.0) \\
& 53(62.4) \\
& 32(37.6)\end{aligned}$ & $\begin{array}{c}<0.001^{\mathrm{c}}{ }^{\mathrm{c}} \\
0.0688^{\mathrm{c}} \\
<0.0011^{\mathrm{c}} \\
<0.0011^{\mathrm{c}} \\
<0.0011^{\mathrm{c}} \\
<0.001^{\mathrm{c}} \\
0.16\end{array}$ \\
\hline
\end{tabular}

\footnotetext{
${ }^{\mathrm{a}}$ Expressed in median (IQR 25-75).

${ }^{\mathrm{b}}$ Expressed in mean $\pm \mathrm{SD}$ (range).

${ }^{c}$ Paired $t$-test: significant difference compared with baseline, $p \leq 0.05$.

${ }^{\mathrm{d}}$ High physical function if predicted percentage is $\geq 82 \%$; low physical function if predicted percentage is $<82 \%$.

SRT, steep ramp test; 6mWT, 6-minute walk test; N/A, not assessed.
} 
Table 3. Weight Loss and (Non) Response Rates

\begin{tabular}{|c|c|c|}
\hline$\% \mathrm{TWL}$ & & \\
\hline 1.5 years $^{\mathrm{a}}$ & $n=85$ & $34.7 \pm 8.6(18.4-55.9)$ \\
\hline 2-3 years $(\text { midterm })^{\mathrm{a}}$ & $n=82$ & $33.3 \pm 9.5(14.2-53.7)$ \\
\hline $4-5$ years (long term) ${ }^{a}$ & $n=72$ & $29.6 \pm 10.4(10.7-51.1)$ \\
\hline Weight regain $(\%)^{\mathrm{a}}$ & $n=80$ & $10.5 \pm 5.8(0.14-25.4)$ \\
\hline $\begin{array}{l}\text { Primary nonresponse, } \\
\text { no. (\%) }\end{array}$ & $n=85$ & $0(0)$ \\
\hline $\begin{array}{l}\text { Secondary nonresponse, } \\
\text { no. }(\%)^{b}\end{array}$ & $n=85$ & $18(21.2)$ \\
\hline $\begin{array}{l}\text { Time to secondary } \\
\text { nonresponse (years) }\end{array}$ & $n=85$ & $5.0(1.0)$ \\
\hline
\end{tabular}

${ }^{\mathrm{a}}$ Expressed in mean $\pm \mathrm{SD}$ (range).

${ }^{\mathrm{b}}$ Secondary nonresponse is defined as a $\% \mathrm{TWL}>15 \%$ and a weight regain of $>15 \%$ after 24 months.

${ }^{\mathrm{c}}$ Expressed in median (IQR 25-75).

TWL, total weight loss.

$33.3 \% \pm 9.5 \%$ at $2-3$ years, and $29.6 \% \pm 10.4 \%$ at $4-5$ years after surgery (Table 3 ). Based on the aforementioned criteria for nonresponse, no patients were classified as primary nonresponse, whereas 18 patients $(21.2 \%)$ were classified as secondary nonresponse. Time to develop secondary nonresponse varied from 4 to 5 years.

\section{Predictors of weight loss and nonresponse}

A stepwise multiple linear regression analysis revealed that both the 24-h dietary recall and $6 \mathrm{mWT}$ were not significantly associated with \%TWL at midterm $(p=0.203$ and $p=0.948)$ nor with \%TWL at long term $(p=0.963$ and $p=0.855)$ (Table 4). Being female $(\beta=0.34 ; p=0.003)$ and having a greater preoperative BMI $(\beta=0.31 ; p=0.006)$ resulted in a higher \%TWL at midterm. Moreover, having a greater preoperative BMI $(\beta=0.35 ; p=0.006)$ resulted in a higher \%TWL at long term. Remarkably, multiple linear regression analysis showed similar results when including protein intake and physical function as continuous variables. When focusing on secondary nonresponse, a multiple logistic regression analysis revealed that protein intake and physical function were not significant predictors (Table 5). Due to the small group of patients with secondary nonresponse $(n=18)$, it was not possible to further assess predictors specifically in this subgroup.

\section{Discussion}

Knowledge on strategies on how to maximize weight loss and reduce the rate of nonresponse after bariatric surgery is crucial. Protein intake and physical function are well-known factors that have a substantial impact on weight loss outcomes ${ }^{9}$ and therefore, a routine assessment of these factors is advised. ${ }^{14,18}$ The 24 -h dietary recall and $6 \mathrm{mWT}$ are feasible tests in today's clinical practice to assess protein intake and physical function, although it is unknown what their predictive value is. The present study was designed to investigate this predictive value on TWL and nonresponse up to 5 years after RYGB.

In contrast to our initial hypothesis, it was found that protein intake as estimated by 24 -h dietary recall was not predictive of TWL. There are three likely causes for this finding. First of all, in this study, the 24-h dietary recall has been used to estimate protein intake only, while there is evidence that a certain amount of carbohydrates along with protein is necessary to preserve fat-free mass. ${ }^{15,29}$ It has also been suggested that energy restriction, rather than the protein diet's content, affects weight outcomes. ${ }^{30,31}$ In detail, caloric intake is known to be reduced in the immediate postoperative phase, but in a subset of patients, energy intake gradually increases over time, which is thought to hinder weight loss

Table 4. Multiple Linear Regression Analysis for Predictors of Percentage of Total Weight Loss at Midterm and Long-Term

\begin{tabular}{|c|c|c|c|c|}
\hline \multirow{3}{*}{ Unadjusted model $^{\mathrm{a}}$} & \multicolumn{2}{|c|}{$\%$ TWL midterm $(\mathrm{n}=82)$} & \multicolumn{2}{|c|}{$\% T W L$ long-term $(\mathrm{n}=72)$} \\
\hline & \multirow[t]{2}{*}{$B$} & \multirow[t]{2}{*}{ p-value } & \multirow[t]{2}{*}{$\beta$} & \multirow[t]{2}{*}{$\mathrm{p}$-value } \\
\hline & & & & \\
\hline Protein intake (adequate vs. inadequate) ${ }^{\mathrm{b}}$ & -0.106 & 0.348 & 0.021 & 0.863 \\
\hline Physical function (high vs. low) ${ }^{\mathrm{c}}$ & 0.045 & 0.639 & 0.053 & 0.663 \\
\hline \multicolumn{5}{|l|}{ Adjusted model $^{\mathrm{d}}$} \\
\hline Protein intake (adequate vs. inadequate) ${ }^{\mathrm{e}}$ & -0.134 & 0.203 & 0.005 & 0.963 \\
\hline Physical function (high vs. low) ${ }^{\mathrm{f}}$ & 0.007 & 0.948 & 0.022 & 0.855 \\
\hline Age & 0.030 & 0.774 & 0.038 & 0.757 \\
\hline Gender (female vs. male) & 0.344 & $0.003^{\mathrm{g}}$ & 0.180 & 0.156 \\
\hline Preoperative BMI & 0.308 & $0.006^{\mathrm{g}}$ & 0.349 & $0.006^{\mathrm{g}}$ \\
\hline Preoperative individual treatment (yes vs. no) & -0.079 & 0.467 & -0.003 & 0.978 \\
\hline Long-term complication (yes vs. no) & 0.034 & 0.743 & -0.024 & 0.841 \\
\hline \multicolumn{5}{|c|}{ Dependent variables: \% TWL midterm and \% TWL long-term. } \\
\hline \multicolumn{5}{|c|}{${ }^{\mathrm{a}}$ Unadjusted model: protein intake and physical function. } \\
\hline \multicolumn{5}{|c|}{${ }^{b}$ Protein intake (g/day) entered as a continuous variable: $\beta=-0.061 ; p=0.594$ and $\beta=-0.147 ; p=0.223$} \\
\hline \multirow{2}{*}{\multicolumn{5}{|c|}{$\begin{array}{l}\text { }{ }^{\mathrm{c}} \text { Physical function (predicted percentage) entered as a continuous variable: } \beta=0.061 ; p=0.594 \text { and } \beta=0.050 ; p=0.667 \text {. } \\
\text { dAdjusted model: protein intake and physical function, age, gender, preoperative BMI, preoperative individual treatment, and long-term } \\
\text { omplication. }\end{array}$}} \\
\hline & & & & \\
\hline \multicolumn{5}{|c|}{ e } \\
\hline \multicolumn{5}{|c|}{$\begin{array}{l}{ }_{\mathrm{f}}^{\mathrm{f}} \text { Physical function (predicted percentage) entered as a continuous variable: } \beta=0.209 ; p=0.208 \text { and } \beta=0.214 ; p=0.253 \\
{ }_{p} \leq 0.05 \text {. }\end{array}$} \\
\hline BMI, body mass index. & & & & \\
\hline
\end{tabular}


Table 5. Multiple Logistic Regression Analysis for Predictors of Secondary Nonresponse

\begin{tabular}{|c|c|c|c|}
\hline & \multicolumn{3}{|c|}{$\begin{array}{c}\text { Secondary } \\
\text { nonresponse }(\mathrm{n}=85)\end{array}$} \\
\hline & $\begin{array}{l}\text { Odds } \\
\text { ratio }\end{array}$ & $95 \% C I$ & $\mathrm{p}$-value \\
\hline \multicolumn{4}{|l|}{ Unadjusted model ${ }^{\mathrm{a}}$} \\
\hline $\begin{array}{l}\text { Protein intake } \\
\quad(\text { ref }=\text { inadequate })^{\mathrm{b}}\end{array}$ & 2.09 & $0.65-6.72$ & 0.219 \\
\hline Physical function $(\mathrm{ref}=\mathrm{low})^{\mathrm{c}}$ & 0.36 & $0.12-1.07$ & 0.066 \\
\hline \multicolumn{4}{|c|}{ Adjusted model $^{\mathrm{d}}$} \\
\hline $\begin{array}{l}\text { Protein intake } \\
\quad(\text { ref }=\text { inadequate })^{\mathrm{e}}\end{array}$ & 2.68 & $0.72-9.97$ & 0.142 \\
\hline Physical function $(r e f=l o w)^{f}$ & 0.32 & $0.09-1.16$ & 0.082 \\
\hline Age & 0.95 & $0.89-1.01$ & 0.081 \\
\hline Gender $(\mathrm{ref}=$ male $)$ & 2.87 & $0.49-16.48$ & 0.237 \\
\hline Preoperative BMI & 0.89 & $0.77-1.02$ & 0.101 \\
\hline $\begin{array}{l}\text { Preoperative individual } \\
\text { treatment }(\mathrm{ref}=\text { no) }\end{array}$ & 3.85 & $1.04-14.2$ & $0.043^{\mathrm{g}}$ \\
\hline $\begin{array}{l}\text { Long-term complication } \\
\quad(\mathrm{ref}=\mathrm{no})\end{array}$ & 0.27 & $0.02-4.18$ & 0.346 \\
\hline
\end{tabular}

Dependent variable: secondary nonresponse, defined as a \%TWL $>15 \%$ and a weight regain of $>15 \%$ after 24 months.

${ }^{\mathrm{a}}$ Unadjusted model: protein intake and physical function.

${ }^{\mathrm{b}}$ Protein intake (g/day) entered as a continuous variable: $\mathrm{OR}=1.01 ; 95 \%$ CI $0.97-1.04, p=0.798$.

${ }^{c}$ Physical function (predicted percentage) entered as a continuous variable: $\mathrm{OR}=0.93 ; 95 \%$ CI $0.87-1.00, p=0.053$.

${ }^{\mathrm{d}}$ Adjusted model: protein intake and physical function, age, gender, preoperative BMI, preoperative individual treatment, and long-term complication.

'Protein intake (g/day) entered as a continuous variable: $\mathrm{OR}=1.00 ; 95 \%$ CI $0.96-1.05, p=0.859$.

${ }^{\mathrm{f}}$ Physical function (predicted percentage) entered as a continuous variable: $\mathrm{OR}=0.92 ; 95 \%$ CI $0.85-1.01, p=0.073$.

${ }^{\mathrm{g}} p \leq 0.05$

$\mathrm{CI}$, confidence interval; ref, reference.

and increase the risk on weight regain. ${ }^{32}$ Lastly, when inquiring the diet of the last $24 \mathrm{~h}$, there is a great demand on the short-term memory of the patients resulting in an under- or overestimation of the real protein intake. Taken together, presumably both protein and carbohydrate, as well as the energetic value of the diet are of important value when predicting weight loss outcomes.

Another important finding of this study was that physical function as estimated by $6 \mathrm{mWT}$ was not predictive of TWL. Yet again, there are several possible explanations for this result. The first explanation could be that this study exclusively focused on physical function, whereas physical activity participation was not taken into account. It is conceivable that the higher the physical activity, the higher the level of physical function; however, contrasting reports have been described focusing on this association. ${ }^{31,33} \mathrm{~A}$ second explanation could be that physical function was measured only once postoperatively, which gives a limited amount of information about the patient's physical status. Third, there is a possible ceiling effect in the $6 \mathrm{mWT}$ for patients with normal or high exercise capacities presurgery, limiting the ability to detect performance improvements from pre- to postpositive. Lastly, there are many external factors (e.g., motivation, coaching effort) that could have influenced the outcomes of the $6 \mathrm{mWT}$.
This retrospective study has multiple limitations that should be mentioned. Because of missing information, $63 \%$ of patients were excluded which may have influenced the generalizability of the study population. Nevertheless, the sample size was calculated in retrospect and showed that the current sample size was sufficient $(n=84)$. Additionally, since we do not have analyzed data about excluded patients, the results might be prone to selection bias. Moreover, the 24-h dietary recall was measured only once postoperatively, which may have resulted in an unreliable measurement. On top of that, our study solely focused on the predictive effect of lifestyle factors (protein intake and physical function) on weight loss outcomes, whereas weight loss outcomes are suggested to have a multifactorial etiology with several patient (e.g., mental health) and surgeryspecific factors playing a role. ${ }^{9}$

Hereafter, in the context of nutritional surveillance, the 24-h dietary recall should be performed at least twice to obtain a reliable estimation of habitual protein intake. ${ }^{34-36}$ When looking for an alternative, multiple days of dietary records (e.g., 5day food diary) optionally with pictures may be a valid choice as it will provide an optimal nutritional (protein) assessment. ${ }^{36} \mathrm{In}$ context of physical surveillance, an ergospirometry to measure peak oxygen uptake (VO2peak) should be preferred as it assesses exercise capacity more reliable without a ceiling effect. ${ }^{18}$ For this study, these assessments were not available presumably because they are more time consuming, require more equipment, and are more expensive hampering their clinical use. In the assessment of physical status, it could be questioned whether it is sufficient to only perform this measurement before an exercise prescription, or it should be performed longitudinally. When performed postoperatively, the outcome can be used for further counseling as well as weight regain prevention.

\section{Conclusions}

There is emerging evidence that successful long-term weight loss is not maintained in a subset of patients after bariatric surgery. This study focused on the predictive value of protein intake and physical function, measured by the 24-h dietary recall and $6 \mathrm{mWT}$, on long-term weight loss outcomes after RYGB. The results showed that neither the 24-h dietary recall, nor the $6 \mathrm{mWT}$ were significant predictors. These tests are therefore in common practice not feasible to predict successful long-term weight loss. Despite this, they are likely to be useful for their intended purposes, which are the examination of an eating pattern and the measurement of physical function. It is suggested to determine the clinical relevance of other monitoring tests, such as a 5-day food diary or ergospirometry, to predict and optimize weight loss after bariatric surgery.

\section{Author Disclosure Statement}

No competing financial interests exist.

\section{Funding Information}

The authors received no financial support for the research, authorship, and/or publication of this article.

\section{References}

1. Sjöström L. Review of the key results from the Swedish Obese Subjects (SOS) trial-a prospective controlled intervention study of bariatric surgery. J Intern Med 2013;273:219-234. 
2. Gloy V, Briel M, Bhatt D, Kashyap S, Schauer P, Mingrone $\mathrm{G}$, et al. Bariatric surgery versus non-surgical treatment for obesity: a systematic review and meta-analysis of randomized controlled trials. BMJ 2013;347:15934.

3. Puzziferri N, Roshek TB, Mayo HG, Gallagher R, Belle $\mathrm{SH}$, Livingston $\mathrm{EH}$. Long-term follow-up after bariatric surgery: a systematic review. JAMA 2014;312:934-942.

4. Magro DO, Geloneze B, Delfini R, Pareja BC, Callejas F, Pareja JC. Long-term weight regain after gastric bypass: a 5-year prospective study. Obes Surg 2008;18:648-651.

5. Cooper TC, Simmons EB, Webb K, Burns JL, Kushner RF. Trends in weight regain following Roux-en-Y gastric bypass (RYGB) bariatric surgery. Obes Surg 2015;25:14741481.

6. Uittenbogaart $M$, Leclercq $\mathrm{W}$, Luijten A, Romeijn M, Bonouvrie D, van Dielen F. Defining an international standard for primary and secondary non-response following bariatric surgery for research purposes: a modified Delphi consensus. Surg Obes Relat Dis 2019;15:S76.

7. Cadena-Obando D, Ramírez-Rentería C, FerreiraHermosillo A, Albarrán-Sanchez A, Sosa-Eroza E, MolinaAyala $\mathrm{M}$, et al. Are there really any predictive factors for a successful weight loss after bariatric surgery? BMC Endocr Disord 2020;20:20.

8. Shantavasinkul PC, Omotosho P, Corsino L, Portenier D, Torquati A. Predictors of weight regain in patients who underwent Roux-en-Y gastric bypass surgery. Surg Obes Relat Dis 2016;12:1640-1645.

9. Karmali S, Brar B, Shi X, Sharma AM, de Gara C, Birch DW. Weight recidivism post-bariatric surgery: a systematic review. Obes Surg 2013;23:1922-1933.

10. Yanos BR, Saules KK, Schuh LM, Sogg S. Predictors of lowest weight and long-term weight regain among Rouxen-Y gastric bypass patients. Obes Surg 2015;25:13641370 .

11. Lupoli R, Lembo E, Saldalamacchia G, Avola CK, Angrisani L, Capaldo B. Bariatric surgery and long-term nutritional issues. World J Diabetes 2017;8:464-474.

12. Cambi MPC, Baretta GAP, Magro DO, Boguszewski CL, Ribeiro IB, Jirapinyo P, de Moura DTH. Multidisciplinary approach for weight regain-how to manage this challenging condition: an expert review. Obes Surg 2021;31:12901303.

13. Mechanick JI, Apovian C, Brethauer S, Garvey WT, Joffe AM, Kim J, et al. Clinical practice guidelines for the perioperative nutrition, metabolic, and nonsurgical support of patients undergoing bariatric procedures-2019 update: cosponsored by American Association of Clinical Endocrinologists/American College of Endocrinology, The Obesity Society, American Society for Metabolic \& Bariatric Surgery, Obesity Medicine Association, and American Society of Anesthesiologists. Surg Obes Relat Dis 2020;16:175-247.

14. Tabesh MR, Maleklou F, Ejtehadi F, Alizadeh Z. Nutrition, physical activity, and prescription of supplements in preand post-bariatric surgery patients: a practical guideline. Obes Surg 2019;29:3385-3400.

15. Faria SL, Faria OP, Buffington C, de Almeida Cardeal M, Ito MK. Dietary protein intake and bariatric surgery patients: a review. Obes Surg 2011;21:1798-1805.

16. Schiavo L, Scalera G, Pilone V, De Sena G, Quagliariello $\mathrm{V}$, Iannelli A, et al. A comparative study examining the impact of a protein-enriched vs normal protein postoperative diet on body composition and resting metabolic rate in obese patients after sleeve gastrectomy. Obes Surg 2017;27:881-888.

17. Wefers JF, Woodlief TL, Carnero EA, Helbling NL, Anthony SJ, Dubis GS, et al. Relationship among physical activity, sedentary behaviors, and cardiometabolic risk factors during gastric bypass surgery-induced weight loss. Surg Obes Relat Dis 2017;13:210-219.

18. Hansen D, Decroix L, Devos Y, Nocca D, Cornelissen V, Dillemans B, et al. Towards optimized care after bariatric surgery by physical activity and exercise intervention: a review. Obes Surg 2020;30:1118-1125.

19. de Vries J, de Boer E. De voedingsanamnese-Methoden voor voedselconsumptieonderzoek van bevolkingsgroepen en individuen. Informatorium voor Voeding en Diëtetiek: Springer 2015:17-53.

20. Karanth MS, Awad NT. Six minute walk test: a tool for predicting mortality in chronic pulmonary diseases. J Clin Diagn Res 2017;11:OC34.

21. Baillot A, Audet M, Baillargeon J, Dionne I, Valiquette L, Rosa-Fortin M, et al. Impact of physical activity and fitness in class II and III obese individuals: a systematic review. Obes Rev 2014;15:721-739.

22. de Souza SAF, Faintuch J, Fabris SM, Nampo FK, Luz C, Fabio TL, et al. Six-minute walk test: functional capacity of severely obese before and after bariatric surgery. Surg Obes Relat Dis 2009;5:540-543.

23. Fried M, Yumuk V, Oppert J, Scopinaro N, Torres A, Weiner R, et al. Interdisciplinary European guidelines on metabolic and bariatric surgery. Obes Surg 2014;24:42-55.

24. Gezondheidsraad. Beweegrichtlijnen 2017. Den Haag: 2017 22-08-2017. Report No.: 2017/08.

25. Butland R, Pang J, Gross E, Woodcock A, Geddes D. Two-, six-, and 12-minute walking tests in respiratory disease. $\mathrm{Br}$ Med J (Clin Res ed) 1982;284:1607.

26. Troosters T, Gosselink R, Decramer M. Six minute walking distance in healthy elderly subjects. Eur Respir J 1999;14: 270-274.

27. Wasserman K, Hanssen JE, Sue D, Casaburi R, Whipp BJ. Principles of Exercise Testing and Interpretation, Third ed. Baltimore, MD, VS: Lippincott, Williams \& Wilkins, 1999.

28. Bonouvrie DS, Uittenbogaart M, Luijten AA, van Dielen FM, Leclercq WK. Lack of standard definitions of primary and secondary (non) responders after primary gastric bypass and gastric sleeve: a systematic review. Obes Surg 2019;29:691-697.

29. Suzuki M. Glycemic carbohydrates consumed with amino acids or protein right after exercise enhance muscle formation. Nutr Rev 2003;61(suppl_5):S88-S94.

30. Westerterp-Plantenga M, Nieuwenhuizen A, Tome D, Soenen S, Westerterp K. Dietary protein, weight loss, and weight maintenance. Annu Rev Nutr 2009;29:21-41.

31. Johnson Stoklossa C, Atwal S. Nutrition care for patients with weight regain after bariatric surgery. Gastroenterol Res Pract 2013;2013:256145.

32. Sarwer DB, Wadden TA, Moore RH, Baker AW, Gibbons LM, Raper SE, et al. Preoperative eating behavior, postoperative dietary adherence, and weight loss after gastric bypass surgery. Surg Obes Relat Dis 2008;4:640646.

33. Josbeno DA, Kalarchian M, Sparto PJ, Otto AD, Jakicic JM. Physical activity and physical function in individuals post-bariatric surgery. Obes Surg 2011;21:1243-1249.

34. De Keyzer W, Huybrechts I, De Vriendt V, Vandevijvere S, Slimani N, Van Oyen H, et al. Repeated 24-hour recalls 
versus dietary records for estimating nutrient intakes in a national food consumption survey. Food Nutr Res 2011;55: 7307.

35. Castell GS, Serra-Majem L, Ribas-Barba L. What and how much do we eat? 24-hour dietary recall method. Nutr Hosp 2015;31:46-48.

36. Yuan C, Spiegelman D, Rimm EB, Rosner BA, Stampfer MJ, Barnett JB, et al. Relative validity of nutrient intakes assessed by questionnaire, 24-hour recalls, and diet records as compared with urinary recovery and plasma concentration biomarkers: findings for women. Am J Epidemiol 2018;187:1051-1063.
Address correspondence to: Marleen M. Romeijn, MD Department of Surgery

Research School NUTRIM Maastricht University Medical Center+ Universiteitssingel 40 Maastricht 6229 ER The Netherlands

E-mail: bariatrics.resurge@mmc.nl 